DOI: $10.22616 /$ REEP.2020.033

\title{
Gender Perception towards Women in Rural Areas in Turkey
}

\author{
Tayfun Cukur ${ }^{1}$ Dr.agr.; Nuray Kızlaslan ${ }^{2}$ Dr.agr.; Halil Kızılaslan ${ }^{3}$ Dr.agr.; Figen Cukur ${ }^{4}$ Dr.agr. \\ Mugla Sitk1 Kocman University, Milas Vocational School, Turkey ${ }^{1,4}$ \\ Tokat Gaziosmanpasa University, Agricultural Faculty, Department of Agricultural Economics, \\ Turkey ${ }^{2,3}$ \\ tayfun.cukur@hotmail.com ${ }^{1}$; nuray.kizilaslan@gop.edu.tr² \\ halil.kizilaslan@gop.edu.tr ${ }^{3}$; figencukur@hotmail.com ${ }^{4}$
}

\begin{abstract}
Women and men have certain roles and responsibilities in social life. These roles and responsibilities are determined by gender. The perception of gender can be different in urban and rural areas. In this research, the gendered perception of women was investigated specifically in Tokat province. 175 women and 125 men in 25 quarters of the central district of Tokat province, who had immigrated from rural to urban areas, were given a questionnaire. The study was aimed at identifying certain views on the family life of the woman, the work life of the woman, whether the man was considered as the leader of the family, and whether these views had a relationship with gender. The study was investigated statistically using Chi-square analysis. The statistical analysis showed that there existed a significant relationship between the views of the participants on gender, and their sex. Rural women believe that women can run businesses, work as managers, continue working after marriage, their working will not hinder their household tasks and they believe that they can work after giving birth more than men do. The majority of the men that took part in the survey think that the man is the family's leader and that men should make the most important decisions. An important part of the men think women are vulnerable and they should be protected.
\end{abstract}

Keywords: gender, rural area, man, woman, gender perception, adults.

\section{Introduction}

The term "gender" and the closely related term "sex" are used interchangeably, and the conceptual differences between the two words are often ignored, especially in everyday conversations. The term "sex" is related to anatomy, physiology and neurology and may also play a role in our behavioural, cognitive and affective characteristics. In general, sex is considered a demographic category based on biological characteristics. The term "gender" is both a cultural and an individual concept and refers to a social and psychological situation imposed or adopted. In other words, gender refers to psychosocial characteristics that characterize people as feminine or masculine (Kizılaslan, Diktas, 2011). Gender role is defined as the relative degree of an individual's feminine or masculine psychological characteristics. The feminine gender role is typically compassionate, emotional, submissive and dependent, while the masculine gender role is typically analytical, assertive, competitive, dominant, adventurous, strong and aggressive (Öngen, 2007).

Gender perceptions in societies can affect people's lives, behaviours, attitudes and expectations. These perceptions impose different roles on women and men in society. In particular, it can be said that these stereotypes have important effects on women's family life and working life. Gender stereotypes are closely linked to traditional social roles and power inequalities between women and men (Prentice, Carranza, 2002).

The effect of gender differences can be seen in many areas such as household labour, earnings, promotion and authority and educational opportunities (Mahaffy, Ward, 2002).

Successful integration of women into the labour market contributes to the development of the entire national economy (Racene, 2016). Women should strike a balance between work, family, mentality, civil society and leisure (Racene, 2013). There are certain differences between male and female personality traits - the man has more manifestation of dominance but woman has more signs of altruism (Badjanova, Ilisko, Ignatjeva, 2019). Women's career development is different and more complex when compared to that of men because women have different tasks and employment opportunities in life and in the family. There are different traditions and stereotypes, which both contributes to and prevents women's career development (Racene, Dislere, 2013). Low-income managers at the beginning of their careers face more career barriers than experienced and high-income women managers (Meral, Otlu, 2016). 
Today, the global gender gap score is $68 \%$. So, there is a $32 \%$ gap to close (World Economic Forum, 2018). Women still earn on average $16 \%$ less than men. The disadvantage of women is directly related to their weak position in the labour market because, even if women participate in working life, they continue to have an important responsibility in the family in terms of housework (Oláh, Richter, Kotowska, 2014).

The leading gender-related problem is gender inequality. Whereas two-thirds of the working hours in the world are filled by women, and women produce more than $50 \%$ of the food produced, they receive only $10 \%$ of the income. While having less than $2 \%$ of property, women can get less than $5 \%$ of all bank loans. The study shows that $70 \%$ of the 1.2 billion people in poverty are women. The number of rural women living in absolute poverty has increased by $20 \%$ in the last twenty years. It is sad to find out that $60 \%$ of the workers working without insurance are women. The study shows that $54 \%$ of the 72 million school-age children who do not go to school are girls. Of the 40 million refugees in the world, $75 \%$ are women and children (Food and Agriculture..., 2011).

Today, the rural population is decreasing all around the world. Among the reasons for this are that men want to work in cities and that they incline to non-agricultural economic activities in rural areas. A study by J.K. Mduma (2014) revealed that rural women did not have geographical mobility, and they preferred to work in the area they lived in. Their study devoted to identifying women's role in the immigration from rural to urban areas (Kizlaslan, 2013) showed that the influence of women on this matter increased with age, higher levels of education, and in cases where they had done research about the area where they were going to move to, or where there was a patriarchal family structure. In a study by G. Ozdemir, G. Unakıtan, G. Keskin, E. Y1lmaz and F. Ülker (Ozdemir et al., 2017) carried out in Trakya Region, it was found out that $90 \%$ of the participating women lived in their village constantly. This renders women more important in agriculture. Table 1 shows the employment rates of men and women in agriculture, forestry, hunting and fishing by years. As can be seen the percentage of women working in these sectors is higher than men. For instance, $27.6 \%$ of men are working in these sectors while the percentage of women is $30.5 \%$ as of 2017. A similar situation is present in Turkey as well, where, in 2016, $15.5 \%$ of men and $28.7 \%$ of women were employed in agriculture (Turkish Statistical Institute, 2018).

\section{Employment rates in agriculture, forestry, hunting and fishing (\%)}

\begin{tabular}{|c|c|c|}
\hline Years & Women & Men \\
\hline 1997 & 41.6 & 38.5 \\
\hline 2007 & 36.5 & 32.5 \\
\hline 2017 & 30.5 & 27.6 \\
\hline
\end{tabular}

Source: (World Employment..., 2017).

According to household workforce research results, while the employment rate for the population at 15 years of age and above was $56 \%$ in 2015, this rate was $46 \%$ in men and $27.5 \%$ in women (Turkish Statistical Institute, 2017). The rate of workforce participation at the age of 15 or above is $71.6 \%$ for men and $31.5 \%$ for women (Table 2).

Table 2

Indicators chosen related with gender (2015) (\%)

\begin{tabular}{|l|c|c|c|}
\hline \multicolumn{1}{|c|}{ Chosen indicators } & Total & Men & Women \\
\hline Illiterate population (25+years) & 5.4 & 1.8 & 9.0 \\
\hline Percentage of Associate or Bachelor degree (25+ years) & 15.5 & 17.9 & 13.1 \\
\hline Employment (15+ years) & 46.0 & 65.0 & 27.5 \\
\hline Participation in workforce (15+ years) & 51.3 & 71.6 & 31.5 \\
\hline Unemployment (15+ years) & 10.3 & 9.2 & 12.6 \\
\hline Young unemployment (15-24 years) & 18.5 & 16.5 & 22.2 \\
\hline
\end{tabular}

Source: (Turkish Statistical Institute, 2017).

Women working in rural areas both mind the home and actively work in agricultural and nonagricultural activities. For this reason, it is of prime importance that women's economic, social and legal rights are protected because the wages of rural women are about $80 \%$ of the wages of men. On the other 
hand, the women working in small family businesses are not paid, and most of these women do not have social security or a regular income (Braziene, 2008).

In order to raise the status of women in the society, it is necessary to know the perceptions and attitudes of individuals about gender inequality. In the current study, it is aimed to make contributions to research to be conducted, decisions to be made and policies to be developed in relation to men and women by determining the societal gender perceptions of men and women. The current research is thought to yield a data set for further research to be conducted for the purpose of reducing societal gender inequality. Therefore, the current study is believed to be important. When the literature is reviewed, it is seen that studies on gender perception of women are mostly directed to women living in urban areas, while studies on rural women are very inadequate. This is the most important feature that distinguishes the current research from previous studies. When the previous studies are examined, it is seen that the gender perceptions have been attempted to be determined only on the basis of the men's or women's opinions. In the current study, interviews have been conducted with both women and men and the attitudes of all the individuals living in rural areas related to gender perception have been evaluated; thus, it can help fill this void in the literature.

In this study, the gender perception of the women living in rural areas was investigated in the province of Tokat. The purpose of the study is to put forward the gender perceptions of the individuals living in the central district of Tokat province and identify the effects of the variable of sex on the perception of gender.

\section{Methodology}

This study consists of surveys given to people that had immigrated from rural areas to Tokat province central district. The priority was given to the 25 quarters that experienced intensive immigration. These quarters account for $50 \%$ of the 52 quarters in Tokat province central district. Using proportional sampling, a total of 300 surveys were carried out on 175 women and 125 men from families that had emigrated from rural areas. Surveys were conducted face to face by researchers. The questionnaires in the current study were administered in November and December, 2017. The data were processed in 2018. The current study employed the "Societal Gender Perception Scale" developed by H.H. Altınova and V. Duyan (Altınova, Duyan, 2013).

In the study, views on the family life of the woman, the work life of the woman, the man's leadership in the family and any statistical relationship between these views and gender were examined using the chisquare analysis.

\section{Results and Discussions}

\section{Several Socio-economical features}

Of the participants of the study, $58.3 \%$ are women and $41.7 \%$ are men. The age average of the participants is 37.9 for women and 50.7 for men. The general age average was 43.2.

In terms of the educational background of women, $25.1 \%$ of the participants were elementary school graduates or lower, but $30.9 \%$ of them were high school graduates and $13.7 \%$ had an associate degree while $30.3 \%$ had a graduate or post-graduate degree. In turn $42.4 \%$ of the men had elementary school education or below; $33.6 \%$ of them were graduates of high school; $12 \%$ held an associate degree and another $12 \%$ had graduate or post-graduate degrees.

Where the participants spent most of their time was investigated. Answering to this question $22.3 \%$ of the women spent most of their time in a village/town, $33.7 \%$ of them spent most of their time in the district, and $44 \%$ of them spent their time in the province. For men, these percentages were $18.4 \%$, $12 \%$, and $69.6 \%$ respectively.

\section{Findings related to gender perception}

Women's participation in the labour force brings economic independence, enhances their health status and increases welfare (Karim et al., 2018). Table 3 shows the results of authors' of this article study and shows the views of individuals on work in relation to statements related with women's working life. In the current study $88.6 \%$ of women and $78.4 \%$ of the men agree with the suggestion "marriage does not prevent a woman from working". 
Only $16 \%$ of the women agree with the statement "A woman must work only if the family is having financial difficulties". The percentage of men that agree with this statement is $48.8 \%$.

Table 3

Statements on women work life

\begin{tabular}{|c|c|c|c|c|c|c|c|c|c|c|}
\hline \multirow[b]{2}{*}{ Statements } & \multirow[b]{2}{*}{ Gender } & \multicolumn{2}{|c|}{ Agree } & \multicolumn{2}{|c|}{ Indecisive } & \multicolumn{2}{|c|}{ Disagree } & \multicolumn{2}{|c|}{ Total } & \multirow[b]{2}{*}{$\mathbf{p}$} \\
\hline & & $\begin{array}{c}\text { Num- } \\
\text { ber }\end{array}$ & $\%$ & $\begin{array}{l}\text { Num- } \\
\text { ber }\end{array}$ & $\%$ & $\begin{array}{l}\text { Num- } \\
\text { ber }\end{array}$ & $\%$ & $\begin{array}{l}\text { Num- } \\
\text { ber }\end{array}$ & $\%$ & \\
\hline \multirow{2}{*}{$\begin{array}{l}\text { Marriage can not prevent } \\
\text { women work life. }\end{array}$} & Women & 155 & 88.6 & 10 & 5.7 & 10 & 5.7 & 175 & 100 & \multirow{2}{*}{$0.008^{*}$} \\
\hline & Men & 98 & 78.4 & 6 & 4.8 & 21 & 16.8 & 125 & 100 & \\
\hline \multirow{2}{*}{$\begin{array}{l}\text { Women should work only if } \\
\text { the family has an economical } \\
\text { trouble. }\end{array}$} & Women & 28 & 16 & 6 & 3.4 & 141 & 80.6 & 175 & 100 & \multirow{2}{*}{$0.000 *$} \\
\hline & & 61 & 48.8 & 15 & 12 & 49 & 39.2 & 125 & 100 & \\
\hline \multirow{2}{*}{$\begin{array}{l}\text { Working women can also spend } \\
\text { enough time with their kids }\end{array}$} & Women & 120 & 68.6 & 38 & 21.7 & 17 & 9.7 & 175 & 100 & \multirow{2}{*}{$0.000 *$} \\
\hline & Men & 49 & 39.2 & 10 & 8 & 66 & 52.8 & 125 & 100 & \\
\hline \multirow{2}{*}{$\begin{array}{l}\text { Women should not work } \\
\text { after becoming a mother }\end{array}$} & Women & 24 & 13.7 & 25 & 14.3 & 126 & 72 & 175 & 100 & \multirow{2}{*}{$0.000^{*}$} \\
\hline & Men & 53 & 42.4 & 16 & 12.8 & 56 & 44.8 & 125 & 100 & \\
\hline \multirow{2}{*}{$\begin{array}{l}\text { Women should not work } \\
\text { after getting married }\end{array}$} & Women & 12 & 6.9 & 13 & 7.4 & 150 & 85.7 & 175 & 100 & \multirow{2}{*}{ 0.000: } \\
\hline & Men & 35 & 28 & 14 & 11.2 & 76 & 60.8 & 125 & 100 & \\
\hline \multirow{2}{*}{$\begin{array}{l}\text { Working life of a woman } \\
\text { won't prevent her domestic } \\
\text { work to be failed }\end{array}$} & Women & 110 & 62.9 & 31 & 17.7 & 34 & 19.4 & 175 & 100 & \multirow{2}{*}{0.001} \\
\hline & Men & 53 & 42.4 & 27 & 21.6 & 45 & 36 & 125 & 100 & \\
\hline \multirow{2}{*}{$\begin{array}{l}\text { A working mother is a better } \\
\text { mother for her children }\end{array}$} & Women & 78 & 44.6 & 59 & 33.7 & 38 & 21.7 & 175 & 100 & \multirow{2}{*}{$0.000 *$} \\
\hline & Men & 44 & 35.2 & 18 & 14.4 & 63 & 50.4 & 125 & 100 & \\
\hline \multirow{2}{*}{$\begin{array}{l}\text { Woman politicians can also } \\
\text { be successful }\end{array}$} & Women & 152 & 86.9 & 9 & 5.1 & 14 & 8 & 175 & 100 & \multirow{2}{*}{0.098} \\
\hline & Men & 99 & 79.2 & 6 & 4.8 & 20 & 16 & 125 & 100 & \\
\hline \multirow{2}{*}{$\begin{array}{l}\text { Women can become } \\
\text { managers }\end{array}$} & Women & 163 & 93.1 & 10 & 5.7 & 2 & 1.2 & 175 & 100 & \multirow{2}{*}{$0.000 *$} \\
\hline & Men & 95 & 76 & 14 & 11.2 & 16 & 12.8 & 125 & 100 & \\
\hline \multirow{2}{*}{$\begin{array}{l}\text { Women should not } \\
\text { commence a business on } \\
\text { their own }\end{array}$} & Women & 12 & 6.9 & 15 & 8.6 & 148 & 84.6 & 175 & 100 & \multirow{2}{*}{$0.000 *$} \\
\hline & Men & 70 & 56 & 7 & 5.6 & 48 & 38.4 & 125 & 100 & \\
\hline
\end{tabular}

$* \mathrm{p}<0.05$ importance level

According to the findings $68.6 \%$ of women who took part in the study thought that working women can allot enough time for their children. However, only $6.9 \%$ of the women agreed with the statement "women should not work after marriage". With regards to men, $28 \%$ said they agreed with this statement. In a study conducted by V.S. Beniwal and B.D. James in India, it was found that $41 \%$ of the participants participated in the statement that "women should not work after marriage." (Beniwal, James, 2019). One of the findings of this study is $13.7 \%$ of the women and $42.4 \%$ of the men agreed with the statement "women should not work after giving birth". A significant number of women $(62.9 \%)$ believed that working would not hinder the household chores of women. It was found out that $44.6 \%$ of the women and $35.2 \%$ of the men agreed with the statement "A working woman will make a better mother".

Women's engagement in politics is a requirement of human rights, which contributes to growth and sustainable development. Women's political empowerment is essential for democratic governance (Women's Political Participation..., 2018). A large majority of the women (86.9\%) agreed with the statement "women can be successful politicians". The percentage of agreement on the statement "women can be managers" was very high. In the current study $93.1 \%$ of women and $76 \%$ of men agreed with the statement. The results of the study show that $84.6 \%$ of the women did not agree with the statement "women should not run businesses alone", which shows that the participants of the surveys thought positively of women's entrepreneurship. In a study by N. Kizilaslan and A. Yamanoglu, in Tokat province, $61.99 \%$ of the women and $55.56 \%$ of the men stated that women should take part in non-agricultural income-generating activities (Kizllaslan, Yamanoglu, 2010). M.K. Davran, N. Koluman-Darcan and D.B. Budak determined in their study that they conducted with the rural women in Adana province that $30 \%$ of the women answered 
the question "what is the difference between the tasks of men and women in agriculture?" saying there was no difference (Davran, Koluman-Darcan, Budak, 2007).

An examination of the views of the participants on the women's participation in the work force shows that a significant difference between men and women was found in all statements except "women politicians can be successful" ( $<<0.05)$. A study carried out by K. Yoshida (2011) in Japan argued that education has a positive effect on gender perception.

Table 4 shows the views of the participants of the study on considering the men as the leader of the family. An important part of the women $(60.6 \%)$ participating in the research disagree with the statement "A woman must not work if her husband does not give consent". G. Aslan (2011) stated that $46.6 \%$ of female students and $10 \%$ of male students strongly disagreed with the statement that "women should get permission from their husbands to work". In a study conducted by V.S. Beniwal and B.D. James, it was found that $51 \%$ of the participants agreed with the statement that "women should always listen to their husbands" (Beniwal, James, 2019).

Table 4

Statements on men being the leader of the family

\begin{tabular}{|c|c|c|c|c|c|c|c|c|c|c|}
\hline \multirow[b]{2}{*}{ Statements } & \multirow[b]{2}{*}{ Gender } & \multicolumn{2}{|c|}{ Agree } & \multicolumn{2}{|c|}{ Indecisive } & \multicolumn{2}{|c|}{ Disagree } & \multicolumn{2}{|c|}{ Total } & \multirow[b]{2}{*}{$\mathbf{P}$} \\
\hline & & $\begin{array}{c}\text { Num- } \\
\text { ber }\end{array}$ & $\%$ & $\begin{array}{l}\text { Num- } \\
\text { ber }\end{array}$ & $\%$ & $\begin{array}{c}\text { Num- } \\
\text { ber }\end{array}$ & $\%$ & $\begin{array}{l}\text { Num- } \\
\text { ber }\end{array}$ & $\%$ & \\
\hline \multirow{2}{*}{$\begin{array}{l}\text { Woman should not work } \\
\text { if her husband does not } \\
\text { allow her to work }\end{array}$} & Women & 39 & 22.3 & 30 & 17.1 & 106 & 60.6 & 175 & 100 & \multirow{2}{*}{$0.000^{*}$} \\
\hline & Man & 85 & 68 & 19 & 15.2 & 21 & 16.8 & 125 & 100 & \\
\hline \multirow{2}{*}{$\begin{array}{l}\text { A working woman } \\
\text { should give her earnings } \\
\text { to her husband }\end{array}$} & Women & 22 & 12.5 & 40 & 22.9 & 113 & 64.6 & 175 & 100 & \multirow{2}{*}{$0.000^{*}$} \\
\hline & Men & 53 & 42.4 & 27 & 21.6 & 45 & 36 & 125 & 100 & \\
\hline \multirow{2}{*}{$\begin{array}{l}\text { A woman should not } \\
\text { earn more than her } \\
\text { husband }\end{array}$} & Women & 36 & 20.6 & 24 & 13.7 & 115 & 65.7 & 175 & 100 & \multirow{2}{*}{ 0.000* } \\
\hline & Man & 55 & 44 & 12 & 9.6 & 58 & 46.4 & 125 & 100 & \\
\hline \multirow{2}{*}{$\begin{array}{l}\text { A woman without a } \\
\text { husband resembles a } \\
\text { house without an owner }\end{array}$} & Women & 54 & 30.9 & 14 & 8 & 107 & 61.1 & 175 & 100 & \multirow{2}{*}{ 0.000* } \\
\hline & Men & 87 & 69.6 & 6 & 4.8 & 32 & 25.6 & 125 & 100 & \\
\hline \multirow{2}{*}{$\begin{array}{l}\text { A family's income } \\
\text { should be provided by } \\
\text { man }\end{array}$} & Women & 51 & 29.1 & 27 & 15.4 & 97 & 55.5 & 175 & 100 & \multirow{2}{*}{ 0.000* } \\
\hline & Men & 80 & 64 & 5 & 4 & 40 & 32 & 125 & 100 & \\
\hline \multirow{2}{*}{$\begin{array}{l}\text { Men should always be } \\
\text { the head of the } \\
\text { household }\end{array}$} & Women & 70 & 40 & 21 & 12 & 84 & 48 & 175 & 100 & \multirow{2}{*}{ 0.000* } \\
\hline & Men & 91 & 72.8 & 4 & 3.2 & 30 & 24 & 125 & 100 & \\
\hline \multirow{2}{*}{$\begin{array}{l}\text { Leadership of the society } \\
\text { should be in men power }\end{array}$} & Women & 33 & 18.9 & 21 & 12 & 121 & 69.1 & 175 & 100 & \multirow{2}{*}{$0.000 *$} \\
\hline & Men & 73 & 58.4 & 6 & 4.8 & 46 & 36.8 & 125 & 100 & \\
\hline \multirow{2}{*}{$\begin{array}{l}\text { Important decisions } \\
\text { about the family should } \\
\text { be made by men }\end{array}$} & Women & 24 & 13.7 & 22 & 12.6 & 129 & 73.7 & 175 & 100 & \multirow{2}{*}{$0.000 *$} \\
\hline & Men & 75 & 60 & 17 & 13.6 & 33 & 26.4 & 125 & 100 & \\
\hline
\end{tabular}

$*_{\mathrm{p}}<0.05$ importance level

In a study by M.K. Davran and N. Tok the female seasonal workers working in potato agriculture in Adana reported that they spent the entire sum of their income on the family's needs and that they did not have any money left for their personal needs (Davran, Tok, 2011). A significant number of the women (64.6\%) disagree with the statement "a woman must give her income to her husband". On the other hand, $42.4 \%$ of the man agree with this statement. In the study conducted by H. Ufuk and Ö. Özgen, the rate of female entrepreneurs sharing their earnings with family members was found to be $51.8 \%$ (Ufuk, Özgen, 2001).

According to the results of the research $30.9 \%$ of the women and $69.6 \%$ of the men agree with the statement "A woman must be married". A significant amount of the participating men (64\%) have the opinion that a family's income should be provided by the man. Similarly, a great majority of the men 
(72.8\%) think that men should always be the leader of the household. In a study conducted by M.K. Davran (2005) with amongst the rural women in Adana specifies that living in a small town shows urban and rural features and that the women are behind men at home and in the social life socially due to the patriarchal structure. The statement "The society's leadership must be in the hands of men" is agreed on by $18.9 \%$ of the women and $58.4 \%$ of the men. In a study conducted by G. Aslan (2011), it was found that $22.2 \%$ of female students and $54.2 \%$ of male students agreed with the statement that "women should not live alone".

While the majority of the women did not agree with the statement "important decisions must be made by the man" $(73.7 \%)$, a significant number of the men agreed with this statement (60\%). D. Devkota, G.P. Rauniyar and W.J. Parker found out that the man is dominant in terms of decisions regarding the family (Devkota, Rauniyar, Parker, 1999). In a study conducted in Nigeria by I.B. Oluwatayo (2009), it was revealed that the financial status of the woman was effective in terms of decision making. A. Schneebaum and K. Mader (2013) stress that the man has a voice in the family, especially regarding financial matters in Europe and that the possibility of making shared decisions will increase if the spouses are on the same level socially and economically (Schneebaum, Mader, 2013). Z. Creelman (2018) found that women's contribution to economic output in agriculture in Australia was $48 \%$, but the share of women in making farm-related decisions was less than $20 \%$.

An examination of the views of the participating individuals on regarding the man as the leader of the family shows a statistically significant difference between men and women in all suggestions $(p<0.05)$.

Social and economic differences are effective on a family decision and these decisions can be shaped in accordance with the family's welfare and financial status. In these decisions, the age, sex, health status, agricultural experience of the family members and the relationship between them are also effective (Devkota, Rauniyar, Parker, 1999). Table 5 presents the opinions of the participating individuals on the statements concerning woman's family life. It is found out in the study that $42.3 \%$ of the women and $69.6 \%$ of men agree with the statement "A woman must be defended or protected by someone else". While the majority of the men (76.8\%) agree with the statement "Housewives can raise children better than working women", this percentage is lower among women $(37.1 \%)$.

Table 5

Statements on women's family life

\begin{tabular}{|c|c|c|c|c|c|c|c|c|c|c|}
\hline \multirow[b]{2}{*}{ Statement } & \multirow[b]{2}{*}{ Gender } & \multicolumn{2}{|c|}{ Agree } & \multicolumn{2}{|c|}{ Indecisive } & \multicolumn{2}{|c|}{ Disagree } & \multicolumn{2}{|c|}{ Total } & \multirow[b]{2}{*}{$\mathbf{P}$} \\
\hline & & $\begin{array}{c}\text { Num- } \\
\text { ber }\end{array}$ & $\%$ & $\begin{array}{c}\text { Num- } \\
\text { ber }\end{array}$ & $\%$ & $\begin{array}{c}\text { Num- } \\
\text { ber }\end{array}$ & $\%$ & $\begin{array}{c}\text { Num- } \\
\text { ber }\end{array}$ & $\%$ & \\
\hline $\begin{array}{l}\text { Women should be } \\
\text { defended or protected by } \\
\text { somebody else }\end{array}$ & $\begin{array}{l}\text { Women } \\
\text { Men }\end{array}$ & $\begin{array}{l}74 \\
87\end{array}$ & $\begin{array}{l}42.3 \\
69.6\end{array}$ & $\begin{array}{l}19 \\
12\end{array}$ & $\begin{array}{l}10.8 \\
9.6\end{array}$ & $\begin{array}{l}82 \\
26\end{array}$ & $\begin{array}{l}46.9 \\
20.8\end{array}$ & $\begin{array}{l}175 \\
125\end{array}$ & $\begin{array}{l}100 \\
100\end{array}$ & 0.000* \\
\hline $\begin{array}{l}\text { Compared to a working } \\
\text { woman, a housewife takes } \\
\text { better care of their children } \\
\text { and raise them }\end{array}$ & $\begin{array}{l}\text { Women } \\
\text { Men }\end{array}$ & $\begin{array}{l}65 \\
96\end{array}$ & $\begin{array}{l}37.1 \\
76.8\end{array}$ & $\begin{array}{l}54 \\
10\end{array}$ & $\begin{array}{l}30.9 \\
8\end{array}$ & $\begin{array}{l}56 \\
19\end{array}$ & $\begin{array}{l}32 \\
15.2\end{array}$ & $\begin{array}{l}175 \\
125\end{array}$ & $\begin{array}{l}100 \\
100\end{array}$ & 0.000* \\
\hline $\begin{array}{l}\text { Men should also do the } \\
\text { housework such as } \\
\text { washing dishes and doing } \\
\text { laundry }\end{array}$ & $\begin{array}{l}\text { Women } \\
\text { Men }\end{array}$ & $\begin{array}{l}143 \\
50\end{array}$ & $\begin{array}{l}81.7 \\
40\end{array}$ & $\begin{array}{l}6 \\
11\end{array}$ & $\begin{array}{l}3.4 \\
8.8\end{array}$ & $\begin{array}{l}26 \\
64\end{array}$ & $\begin{array}{l}14.9 \\
51.2\end{array}$ & $\begin{array}{l}175 \\
125\end{array}$ & $\begin{array}{l}100 \\
100\end{array}$ & 0.000* \\
\hline $\begin{array}{l}\text { Women should be younger } \\
\text { than the husband }\end{array}$ & $\begin{array}{l}\text { Women } \\
\text { Men }\end{array}$ & $\begin{array}{l}83 \\
76\end{array}$ & $\begin{array}{l}47.5 \\
60.8\end{array}$ & $\begin{array}{l}34 \\
7\end{array}$ & $\begin{array}{l}19.4 \\
5.6\end{array}$ & $\begin{array}{l}58 \\
42\end{array}$ & $\begin{array}{l}33.1 \\
33.6\end{array}$ & $\begin{array}{l}175 \\
125\end{array}$ & $\begin{array}{l}100 \\
100\end{array}$ & 0.002* \\
\hline $\begin{array}{l}\text { In order to have her own } \\
\text { rights, a woman should be } \\
\text { able to oppose to her } \\
\text { husband if necessary }\end{array}$ & $\begin{array}{l}\text { Women } \\
\text { Men }\end{array}$ & $\begin{array}{l}107 \\
52\end{array}$ & $\begin{array}{l}61.1 \\
41.6\end{array}$ & $\begin{array}{l}19 \\
11\end{array}$ & $\begin{array}{l}10.9 \\
8.8\end{array}$ & $\begin{array}{l}49 \\
62\end{array}$ & $\begin{array}{l}28 \\
49.6\end{array}$ & $\begin{array}{l}175 \\
125\end{array}$ & $\begin{array}{l}100 \\
100\end{array}$ & 0.001* \\
\hline $\begin{array}{l}\text { Women's primary job is to } \\
\text { take care of domestic work }\end{array}$ & $\begin{array}{l}\text { Women } \\
\text { Men }\end{array}$ & $\begin{array}{l}53 \\
86\end{array}$ & $\begin{array}{l}30.3 \\
68.8\end{array}$ & $\begin{array}{l}21 \\
4\end{array}$ & $\begin{array}{l}12 \\
3.2\end{array}$ & $\begin{array}{l}101 \\
35\end{array}$ & $\begin{array}{l}57.7 \\
28\end{array}$ & $\begin{array}{l}175 \\
125\end{array}$ & $\begin{array}{l}100 \\
100\end{array}$ & 0.000* \\
\hline
\end{tabular}

$* \mathrm{p}<0.05$ importance level 
To the question, "Who do you think should marry?" $78.9 \%$ of women said that men; while $21.1 \%$ of men replied that it was irrelevant who made the proposal. The question "If you want to have a baby, do you prefer a gender?" was answered as "a girl" by $19.4 \%$ of the women, $14.3 \%$ said they wanted a boy and $66.3 \%$ said it did not matter. For the same question, $1.6 \%$ of the men said they wanted girls; $26.4 \%$ said they wanted boys and $72 \%$ said it did not matter.

It is determined in the study that $81.7 \%$ of the women agree with the statement "Men must also do household chores". In a study by N. Kizılaslan and A. Yamanoglu, it was detected that $81.29 \%$ of the women and $72.51 \%$ of the men said that men also should take part in cooking, cleaning and taking care of children (Kizilaslan, Yamanoglu, 2010). It is found out in the study that $60.8 \%$ of the men and $47.5 \%$ of the women think that the woman should be younger than her husband. A significant percentage of women $(61.1 \%)$ are of the idea that women should oppose their husbands to protect their own rights. The statement "the primary task of a woman is doing the housework" is agreed on by $30.3 \%$ of the women and $68.8 \%$ of the men.

An examination of the views of the individuals that took part in this study on the woman's family life shows a statistically significant difference between men and women in all suggestions $(p<0.05)$.

\section{Conclusions}

In this study, devoted to identifying the gender perception in rural areas, the statements regarding the topic were examined under three groups. Whether the existence of a relationship between sex and views on gender was also investigated. A broad examination of the statements concerning the working life of women shows that rural women lean towards women entering working life more than men. Rural women believe that women can run businesses, work as managers, continue working after marriage, their working will not hinder their household tasks and they believe that they can work after giving birth more than men do.

When the suggestions that the man is the leader of the family are broadly examined, one can see that rural men demonstrate a more traditional attitude and they adopt a patriarchal mind-set. The majority of the men that took part in the survey think that the man is the family's leader and that men should make the most important decisions. Also, they think that the man should be the breadwinner of the household and that the woman should not earn more than her husband.

A general review of the suggestions about the woman's family life puts forward that the traditional mind-set of the rural men is present here as well. Because the majority of the men think women are vulnerable and they should be protected. For men, the principal duty of women is to do housework.

In the light of the findings obtained in the study, several recommendations can be made. Education should be given to especially rural men to change their patriarchal attitude and mind-set, and social projects should be developed. On the other hand, the positive attitude of women towards working life and entrepreneurship will facilitate their entrance to working life. For this reason, entrepreneurship courses should be opened in rural areas and their integration in working life should be fastened via support programs and loaning facilities.

\section{Bibliography}

1. Altınova H.H., Duyan V. (2013). Toplumsal cinsiyet algısı ölçeğinin geçerlik ve güvenirlik çalışması [The validity and reliability of perception of gender scale]. Society and Social Work, 24(2), 9-22. Retrieved from http://www.acarindex.com/dosyalar/makale/acarindex-1423931177.pdf (in Turkish)

2. Aslan G. (2011). Gender perceptions of preservice teachers. International Journal of Social Sciences and Humanity Studies, 3(2), 241- 254. Retrieved from http://www.sobiad.org/eJOURNALS/journal_IJSS/arhieves/2011_2/gulay_aslan.pdf

3. Badjanova J., Ilisko D., Ignatjeva S. (2019). Critical Evaluation of Personality Traits and Behavioural Gender Peculiarities of Latvian Males and Females. In V. Dislere (Ed.), The Proceedings of the International Scientific Conference Rural Environment. Education. Personality (REEP), 12. Jelgava: Latvia University of Life Sciences and Technologies, 28-33. doi: 10.22616/REEP.2019.003 
4. Beniwal V.S., James B.D. (2019). Women in Indian public administration: prospects and challenges. Journal of Public Administration and Governance, 9(3), 210-224. doi: 10.5296/jpag.v9i3.10947

5. Braziene R. (2008). Final Report Annex I- Country Studies Lithuania. In Poverty and Social Exclusion in Rural Areas. European Commission, 243-261. Retrieved from https://www.researchgate.net/publication/237103993_poverty_and_social_exclusion_in_rural_areas

6. Creelman Z. (2018). Sharing the load: improving technical skills and competencies of women on farms. Rural Extension \& Innovation Systems Journal, 14(1), 147-151. Retrieved from https://www.apen.org.au/static/uploads/files/reis-2018-1401-p7-wfgioggkkgcm.pdf

7. Davran M.K. (2005). Gender roles of rural women in small districts of Adana province, Turkey. Pakistan Journal of Social Sciences,3(1), 56-61.

8. Davran M.K., Koluman-Darcan N., Budak D.B. (2007). Gender role in the small ruminant sector in mountain area of Turkey. Journal of Applied Animal Research, 31(1), 93-95. doi: 10.1080/09712119.2007.9706638

9. Davran M.K., Tok N. (2011). Gender analysis in agricultural enterprises producing early potatoes in the Adana province of Turkey. African Journal of Agricultural Research, 6(2), 376-381. Retrieved from https://academicjournals.org/journal/AJAR/article-full-text-pdf/8ACA99F37913

10. Devkota D., Rauniyar G.P., Parker W.J. (1999). The role of gender and ethnicity in household decision-making: evidence from rural Nepal. Retrieved from https://econpapers.repec.org/paper/agsaare99/123801.htm

11. Food and Agriculture Organization of the United Nations. (2011). Communicating Gender for Rural Development Integrating Gender in Communication for Development. Brussels: Dimitra Project. Retrieved from http://www.fao.org/3/am319e/am319e00.pdf

12. Karim R., Lindberg L., Wamala S., Emmelin M. (2018). Men's perceptions of women's participation in development initiatives in rural Bangladesh. American Journal of Men's Health, 12(2), 398-410. doi: 10.1177/1557988317735394

13. Kizılaslan D., Diktas I.O. (2011). The role of university education in changing the gender role perceptions of Turkish ELT student teachers. International Online Journal of Educational Sciences, 3(2), 510-525. Retrieved from http://mts.iojes.net//userfiles/Article/IOJES_482.pdf

14. Kızılaslan N. (2013). Kırdan Kente Göç Olgusunda Kadının Rolü ve Göç Kararındaki Etkisinin Analizi Tokat İli Örneği [The Role of Women in Migration from Rural to Urban and Analysis of the Impact on Migration Decision Case of Tokat Province]. Gaziosmanpaşa University Agricultural Faculty Publications No: 75, Research Series No: 27, 111. Tokat. (in Turkish)

15. Kızılaslan N., Yamanoglu A. (2010). Social gender analysis in a Turkish province. The province of Tokat: a case study, New Medit, 3, 76-80. Retrieved from https://newmedit.iamb.it/share/img_new_medit_articoli/314_76kizilaslan.pdf

16. Mahaffy K.A., Ward S.K. (2002). The gendering of adolescents' childbearing and educational plans: reciprocal effects and the influence of social context. Sex Roles, 46(11-12), 403-417.

17. Mduma J.K. (2014). Gender differences in rural off-farm employment participation in Tanzania: is spatial mobility an issue? African Journal of Economic Review, 11(1), 3-24. Retrieved from https://www.ajol.info/index.php/ajer/article/view/116287

18. Meral Y., Otlu F.E. (2016). Career barriers (glass ceiling) of women managers' and a research about the reasons. International Journal of Business Marketing and Management, 1(2), 26-38. Retrieved from http://www.ijbmm.com/paper/Sep2016/9971864269.pdf

19. Oláh L.S., Richter R., Kotowska I.E. (2014). The new roles of men and women and implications for families and societies. Families and Societies, 11. Retrieved from http://www.familiesandsocieties.eu/wp-content/uploads/2014/12/WP11OlahEtAl2014.pdf

20. Oluwatayo I.B. (2009). Gender considerations in decision making in rural Nigeria: implications on households' food security in Ekiti state. Poster Presentation - IFRES Project), 21-23 May, 2009 at Accra, Ghana.

21. Ozdemir G., Unakıtan G., Keskin G., Yılmaz E., Ulker FE. (2017). Tarım işletmelerinde kadınların yarattığı işgücü değeri ve örgütlenme yaklaşımları: Trakya bölgesi örneği [Women's contribution of labor force and approach to organization in agriculture enterprises: case of Trakya region]. Journal of Social Policy Studies, 39, 33-58. Retrieved from https://dergipark.org.tr/en/download/article-file/399595 (in Turkish) 
22. Öngen D.E. (2007). The relationship between sensation seeking and gender role orientations among Turkish University students. Sex Roles, 57(1-2), 111-118. doi: 10.1007/s11199-007-9214-4

23. Prentice D.A., Carranza E. (2002). What women and men should be, shouldn't be, are allowed to be, and don't have to be: The contents of prescriptive gender stereotypes. Psychology of Women Quarterly, 26(4), 269-281. doi: 10.1111/1471-6402.t01-1-00066

24. Racene A. (2013). Factors Determining Successful Women Careers. In V. Dislere (Ed.), The Proceedings of the International Scientific Conference Rural Environment. Education. Personality (REEP), 6. Jelgava: LLU, 138-145. Retrieved from https://lufb.llu.lv/conference/REEP/2013/LatviaUniv-Agricult_REEP_2013_ISSN_2255-808X-138-145.pdf

25. Racene A., Dislere V. (2013). A career development support programme for women in professional crisis situations. European Integration Studies, 7, 42-50. doi: 10.5755/j01.eis.0.7.4183

26. Racene A. (2016). The Model of Career Crisis Management for Women as a Means of Career Development in Relation to Lifelong Education. In V. Dislere (Ed.), The Proceedings of the International Scientific Conference Rural Environment. Education. Personality (REEP), 9. Jelgava: LLU, 229-238. Retrieved from https://llufb.llu.lv/conference/REEP/2016/Latvia-UnivAgricult-REEP-2016proceed2255-808X-229-238.pdf

27. Schneebaum A., Mader K. (2013). The gendered nature of intra-household decision making in and across Europe. Department of Economics Working Paper Series, 157. Vienna: WU Vienna University of Economics and Business. Retrieved from https://ideas.repec.org/p/wiw/wiwwuw/wuwp157.html

28. Turkish Statistical Institute. (2017). Haber Bülteni [News Bulletin], No 24643. (in Turkish)

29. Turkish Statistical Institute. (2018). Cinsiyet Göstergeleri [Gender Indicators] [Fact sheet]. Retrieved from http://www.turkstat.gov.tr/PreIstatistikTablo.do?istab_id=1139 (in Turkish)

30. Ufuk H., Özgen Ö. (2001). The profile of women entrepreneurs: a sample from Turkey. International Journal of Consumer Studies, 25(4), 299-308. doi: 10.1046/j.1470-6431.2001.00197.x

31. The Global Gender Gap Report. (2018). Geneva: World Economic Forum. Retrieved from http://www3.weforum.org/docs/WEF_GGGR_2018.pdf

32. Women's Political Participation in Egypt Barriers, opportunities and gender sensitivity of select political institutions. (2018). OECD. Retrieved from http://www.oecd.org/mena/governance/womenspolitical-participation-in-egypt.pdf

33. World Employment Social Outlook: Trends Women 2017. (2017). Genova: International Labour Organization. Retrieved from https://www.ilo.org/global/research/global-reports/weso/trends-forwomen2017/lang--en/index.htm

34. Yoshida K. (2011). Gender Perceptions in Southeast Asian Countries: Findings from JICA-RI Value Surveys, Washington, DC: World Bank. https://www.jica.go.jp/jicari/publication/other/jrft3q0000002ald-att/JICA-RI_Southeast_Asia_Yoshida.pdf 